\title{
In vivo antimalarial activity of the crude leaf extract and solvent fractions of Croton macrostachyus Hocsht. (Euphorbiaceae) against Plasmodium berghei in mice
}

\author{
Laychiluh Bantie ${ }^{1}$, Solomon Assefa', ${ }^{1}$ Tilahun Teklehaimanot ${ }^{2}$ and Ephrem Engidawork ${ }^{1 *}$
}

\begin{abstract}
Background: The issue of resistance in malarial infection makes development of novel drugs a necessity. An alternative source for discovering such drugs is natural products. Croton macrostachyus H. (Euphorbiaceae) is used in Ethiopian folklore medicine for the treatment of malaria and found to possess antimalarial activity in vitro. However, no further scientific investigations have been carried out to substantiate the claim. This study therefore aimed at investigating the in vivo antiplasmodial activity of $80 \%$ methanol extract and solvent fractions of the leaves of Croton macrostachyus $\mathrm{H}$. in rodent model of malaria.
\end{abstract}

Methods: A rodent malaria parasite, Plasmodium berghei, was used to inoculate healthy male Swiss Albino mice of age 6-8 weeks and weight 23-27 g. A hydro-alcoholic crude extract and the solvent fractions (chloroform, methanol and aqueous) were administered at different doses 200, 400 and $600 \mathrm{mg} / \mathrm{kg}$. Parameters, including parasitemia, survival time, body weight, temperature, and packed cell volume were then determined using standard tests such as Peter's and Rane's test.

Results: Chemoprotective effect exerted by the crude extract and fractions ranged between $44-91 \%$ and $12-76 \%$, respectvely. The chemotherapeutic effect of the crude extract and chloroform fraction was in the range of 39-83\% and $66-82 \%$, respectively. Maximum effect in both tests was observed with the larger dose of the crude extract and chloroform fraction. The crude extract prevented loss of weight and reduction in temperature but did not affect packed cell volume. However, the chloroform fraction did also reverse reduction in packed cell volume due to the absence of saponins in the fraction.

Conclusions: The results collectively indicate that the plant has a promising antiplasmodial activity against Plasmodium berghei, which upholds the earlier in vitro findings as well as its folkloric use. Thus, it could be considred as a potential source to develop new antimalarial agents.

Keywords: Antimalarial activity, Plasmodium berghei, Croton macrostachyus, Chloroform fraction, In vivo study

\section{Background}

Malaria is a major public health concern in the world, causing an estimated 0.7-1 million deaths per year. Approximately, half of the world's population is at risk of malaria $[1,2]$ and the vast majority of cases $(78 \%)$ occur in the African region followed by Southeast Asia (15\%)

\footnotetext{
* Correspondence: ephrem.engidawork@aau.edu.et

'Department of Pharmacology and Clinical Pharmacy, School of Pharmacy, Addis Ababa University, P.O, Box 1176, Addis Ababa, Ethiopia

Full list of author information is available at the end of the article
}

and Eastern Mediterranean regions (5\%) [3]. Even though the disease is preventable and curable, it is still one of the greatest global public health challenges especially in subSaharan Africa [4].

There is broad consensus on the need for development of new agents, owing to the increasing resistance of the parasite to available agents. Antimalarial drug development can follow several strategies, ranging from minor modifications of existing agents to 
the design of novel agents that act against new targets [5]. Natural products are the source of the two most important drugs currently available to treat severe falciparum malaria, quinine and artemisinin derivatives. In case of artemisinin, relatively simple chemical modifications of the natural parent compound have led to the synthesis of a series of highly potent antimalarials [6,7]. The development of these two important drugs from natural sources and the utilization of many plants traditionally in various parts of the world triggered the search for new antimalarial drugs of natural origing using in vitro and in vivo studies.

Croton macrostachyus H. (Euphorbiaceae) is commonly found on forest edges along rivers, around lakes, woodlands, wooded grasslands and along roadsides. It is native to Eritrea, Ethiopia, Kenya, Nigeria, Tanzania and Uganda [8,9]. In Ethiopia, it is used for the treatment of malaria by the Shinasha, Agew-awi and Amhara people [10]. Recently, fourteen secondary metabolites have been isolated from Croton macrostachyus and five of them were isolated from the genus for the first time. The compunds include phenolics and triterpenes of the lupane and hopane groups [11].

Ethnobotanical/pharmacological studies revealed that Croton macrostachys has a wide range of activities. The plant has shown a promising antimicrobial [12], antidiabetic [8], purgative and anti-inflammatory effects [13]. The ethyl acetate extract of the stem bark [14] as well as the methanol and dichloromethane extracts of the leaves and stem bark of the plant have been demonstrated to possess significant antibacterial and antifungal activities $[15,16]$. An in vitro study of the fruit extract indicated that the plant had a good antiplasmodial activity [17]. Moreover, the methanol leaf extract of Croton macrostachyus exhibited larvicidal activity against late third instar larvae of Anopheles arabiensis Patton, a potent malaria vector in Ethiopia [18].

About $80 \%$ of the Ethiopian population use traditional medicine due to the cultural acceptability of healers, the relatively low cost of traditional medicine and the difficulty of accessing modern health facilities [19]. The studies conducted on the traditional medicinal plants in Ethiopia are, however, scanty when compared with the multiethnic cultural diversity as well as the diverse flora of Ethiopia. Although recently there are efforts to identify and screen antimalarial herbs used in the ethnomedicine practice of the country, the studies done are very limited and not fully exploratory. Most of them focused on reviewing the ethnobotanical uses of the plant rather than pharmacological screening [20]. Thus, based on ethnobotanical and in vitro studies mentioned above, the present study evaluated the in vivo antimalarial activity of the crude extract and solvent fractions of Croton macrostachyus $\mathrm{H}$.

\section{Methods}

\section{Plant material}

Fresh leaves of Croton macrostachyus H. were collected in October 2010 from Shindi district of Amhara regional state, $420 \mathrm{~km}$ North West of Addis Ababa. The fresh leaves were wrapped with plastic sheets during transportation. The plant was identified as Croton macrostachyus by a taxonomist and a voucher specimen was deposited (No. LB 001) at the National Herbarium, College of Natural Sciences, Addis Ababa University for future reference.

\section{Animals and parasite}

Male Swiss albino mice (age 6-8 weeks and weight of 23-27 g) bred and maintained at the Ethiopian Health Nutrition and Research Institute were used. They were maintained under standrad condition (temperature of $22 \pm 3^{\circ} \mathrm{C}$, relative humidity of $40-50 \%$ and $12 \mathrm{~h}$ light/ $12 \mathrm{~h}$ dark cycle), with food and water ad libitum in the animal house of Akililu Lemma Institute of Pathobiology, Addis Ababa University. Animals were acclimatized for one week to the experimental environment. The care and handling was according to international guidelines for the use and maintenance of experimental animals [21] and the School of Pharmacy Ethics committee approved the protocol.

Chloroquine sensitive strain of Plasmodium berghei (ANKA) obtained from the Department of Biology, College of Natural Sciences, Addis Ababa University was used. The parasites were maintained by serial passage of blood from infected mice to non-infected ones on weekly basis.

\section{Extraction \\ Crude extract}

The leaves were air dried at room temperature under shade and reduced to appropriate size by grinding with an electric mill. A total of $(600 \mathrm{~g})$ dried leaves were extracted by maceration (100 g of dried leave in $600 \mathrm{ml}$ of $80 \%$ methanol) for $72 \mathrm{~h}$. The extraction process was facilitated by using an orbital shaker at $120 \mathrm{rpm}$. The mixture was first filtered using gauze and then with Whatman filters paper No. 1 (What$\operatorname{man}^{\oplus}$, England). The residue was re-macerated for another $72 \mathrm{~h}$ twice and filtered. The combined filtrates were then dried by rotary evaporator (Buchi Rota vapor, Switzerland) at a temperature of $40^{\circ} \mathrm{C}$. After drying, a total of $74.4 \mathrm{~g}$ of dry extract was harvested 
(18.6\% yield) and the dried extract was kept at $-20^{\circ} \mathrm{C}$ until use.

\section{Solvent fractionation}

The crude extract, after defatted with petroleum ether, was subjected to successive extraction in soxhlet apparatus using solvents with differing polarity (chloroform, absolute methanol and distilled water). The dried crude hydroalcoholic extract was placed in a cellulose thimble in an extraction chamber, which was placed on top of a collecting flask beneath a reflux condenser. Chloroform was first added to the flask, and the set up was heated under reflux. When a certain level of condensed solvent accumulated in the thimble, it was siphoned into the flask beneath and continued for 3 days [22] to get the chloroform fraction. The residue left in the thimble was next extracted using methanol following the same procedure as above to get the methanol fraction. The chloroform fraction was air dried at room temperature, while the methanol fraction was removed by using rotary evaporator. The residue left inside the thimble from the two solvent fractions was macerated in Erlenmeyer flask using distilled water to get the aqueous fraction. The aqueous fraction was then concentrated in a water bath and further dried using a lyophilizer (Operan, Korea vacuum limited, Korea). The yield of the dried fraction was $11.2 \%, 27.6 \%$ and $44.6 \%$ for the chloroform, methanol and aqueous fractions, respectively. The dried fractions were then transferred into separate vials and stored at $-20^{\circ} \mathrm{C}$ until use.

\section{Acute toxicity testing}

Twelve female Swiss albino mice were randomly divided into 2 groups of 6 mice per group. After being fasted for $2 \mathrm{~h}$ [21,23], mice in the first group were given $2 \mathrm{~g} / \mathrm{kg}$ and the second group $5 \mathrm{~g} / \mathrm{kg}$ of the crude extract orally and observed for any signs of toxicity daily for 14 days to assess safety of the extract. Animals were observed for gross changes such as loss of appetite, hair erection, lacrimation, tremors, convulsions, salivation, diarrhoea, mortality and other signs of overt toxicity [21].

\section{In vivo antimalarial tests}

\section{Parasite inoculation}

Albino mice previously infected with Plasmodium berghei and having parasitemia level of $20-30 \%$ were used as donor. The donor mice were then sacrificed by decapitation and blood was collected by cardiac puncture into heparinized vacutainer tube containing $0.5 \%$ trisodium citrate. The blood was then diluted with physiological saline $(0.9 \%)$ based on parasitemia level of the donor mice and the red blood cell (RBC) count of normal mice [24], in such a way that $1 \mathrm{ml}$ blood contains $5 \times 10^{7}$ infected RBCs. Each mouse was then given $0.2 \mathrm{ml}$ of this diluted blood intraperitoneally, which contained $1 \times 10^{7}$ Plasmodium berghei infected RBCs.

\section{Grouping and dosing of animals}

For evaluating the crude extract, infected mice were randomly divided into five groups of 6 mice per group. Group I-III were treated with the crude extract of Croton macrostachyus at $200 \mathrm{mg} / \mathrm{kg}$ (CM200), $400 \mathrm{mg} / \mathrm{kg}$ (CM400) and $600 \mathrm{mg} / \mathrm{kg}$ (CM600), repectively. The remaining two groups served as negative and positive controls and administered distilled water (CON) $(2 \mathrm{ml} / 100 \mathrm{~g})$ [15] and chloroquine $25 \mathrm{mg} / \mathrm{kg}$ (CQ25), respectively.

The study on the fractions was conducted using thirty mice for each fraction. Mice were randomly assigned into three treatment groups and two controls, six mice per group for each fraction. Negative controls were administered the vehicle used for reconstitution (Tween 80 $2 \% \mathrm{v} / \mathrm{v}$ in water for the chloroform and methanol fractions or distilled water for the aqueous fraction) (CON). Treatment groups were given the fractions at a dose of $200 \mathrm{mg} / \mathrm{kg}, 400 \mathrm{mg} / \mathrm{kg}$ and $600 \mathrm{mg} / \mathrm{kg}$ dissolved in the respective vehicle. The last group was treated with the standard, CQ25. Doses were selected based on acute toxicity studies. Volume administered was $0.2 \mathrm{ml}$ and gavage was used for oral administration.

\section{The 4 day suppressive test}

This test was used to evaluate the schizontocidal activity of the extract and the fractions against Plasmodium berghei infected mice according to the method described by Peter et al. [25]. Infected mice were randomly divided into their respective group as described under grouping and dosing. Treatment was started three hours after mice had been inoculated with the parasite on day 0 and then continued daily for four days from day 0 to day 3 . After treatment was completed, thin blood film was prepared from the tail of each animal on day 4 to determine parasitemia and percentage inhibition. In addition, each mouse was observed daily for determination of survival time.

\section{Rane's test}

Evaluation of the curative potential of the crude extract and the most active fraction in Peter's test was carried out according to the method described by Ryley and Peters [26]. On Day 0, standard inocula of $1 \times 10^{7}$ infected erythrocytes were inoculated in mice intraperitoneally. Seventy-two hours later, mice were randomly divided into their respective groups and dosed accordingly once daily for five days. Geimsa stained thin blood film was prepared from the tail of each mouse daily for 5 days to monitor parasitemia level. Mean survival time for each group was determined 
arithmetically by calculating the average survival time (days) of mice starting from date of infection over a period of 30 days (D0-D29).

\section{Packed cell volume measurement}

Packed cell volume (PCV) was measured to predict the effectiveness of the test extract and fractions in preventing hemolysis resulting from increasing parasitemia associated with malaria. Heparinized capillary tubes were used for collection of blood from tail of each mouse. The capillary tubes were filled with blood up to $34^{\text {th }}$ of their volume and sealed at the dry end with sealing clay. The tubes were then placed in a micro-hematocrit centrifuge (Gelma Awhksley, England) with the sealed end outwards and centrifuged for $5 \mathrm{~min}$ at 11,000 rpm. The tubes were then taken out of the centrifuge and PCV was determined using a standard Micro-Hematocrit Reader (Hawksley and Sons, England). PCV is a measure of the proportion of RBCs to plasma and measured before inoculating the parasite and after treatment using the following relationship:

$\mathrm{PCV}=\frac{\text { Volume of erythrocytes in a given volume of blood }}{\text { Total blood volume }}$

\section{Parasitemia measurement}

Thin smears of blood were made from the tail of each mouse on day 4 for Peter's test and on day 3-7 for Rane's test. The smears were applied on microscope slides $(76 \times 26 \mathrm{~mm})$ (Menzel-Glaser, Germany), fixed with absolute methanol for $15 \mathrm{~min}$ and stained with $10 \%$ Geimsa stain at $\mathrm{pH} 7.2$ for $15 \mathrm{~min}$. The stained slides were then washed gently using distilled water and air dried at room temperature. Two stained slides for each mouse were examined under Olympus microscope (CHK2-F-GS, Taiwan) with an oil immersion nosepiece of 100× magnification. Three different fields on each slide were examined to calculate the average parasitemia as shown below [27].

$$
\% \text { Parasitemia }=\frac{\text { Number of parasitized RBC }}{\text { Total number of RBC }} \times 100
$$

Finally, percent parasitemia suppression of the extracts was compared with respect to the controls and parasitemia suppression was calculated using the following formula [28].

\section{Monitoring of body weight and temperature changes}

For Peter's test, body weight of each mouse was measured before infection (day 0 ) and on day 4 using a sensitive digital weighing balance (Mettler Toledo, Switzerland). Rectal temperature was also measured by a digital thermometer before infection, four hours after infection and then daily. For Rane's test, body weight and temperature were measured before infection and from day 3-7 after infection. In order to rule out the effect of the extract on body weight, temperature and PCV; the crude extract was administered to healthy mice at the doses used for four days. The extract was found to have no effect on temperature and PCV. However, the larger dose of the crude extarct (CM600) was found to significantly reduce body weight of healthy mice.

\section{Phytochemical screening}

The crude extract and solvent fractions were screened for the presence of different secondary metabolites following standard procedures [29-32].

\section{Data analysis}

Data are expressed as mean \pm standard error of mean (SEM). Data were analyzed using Windows SPSS Version 16.0. One-way analysis of variance (ANOVA) followed by Tukey's HSD post-hoc test was used to determine statistical significance for comparison of parasitemia suppression, weight, PCV, rectal temperature and survival time among groups. P-value of less than 0.05 was considered statistically significant.

\section{Results}

\section{Acute toxicity study}

The acute toxicity study indicated that the extract caused no mortality in both doses ( 2 and $5 \mathrm{~g} / \mathrm{kg}$ ) within the first $24 \mathrm{~h}$ as well as for the following 14 days. Physical and behavioural observations of the experimental mice also revealed no visible signs of overt toxicity like lacrimation, loss of appetite, tremors, hair erection, salivation, diarrhoea and the like. This suggests that LD50 of the extract is greater than $5 \mathrm{~g} / \mathrm{kg}$.

\section{Effect on four day suppressive test Crude extract}

The results of the study showed that the extract displayed chemosuppressive activity against Plasmodium berghei (Table 1). Percentage inhibition analysis indicated that the extract produced a dose-dependent

$$
\% \text { suppression }=\frac{\text { mean parasitemia of negative control-mean parasitemia of treated group }}{\text { mean parasitemia of negative control }} \times 100
$$


Table 1 Parasitemia and survival time of infected mice treated with crude extract and solvent fractions of Croton macrostachys in the 4 day suppressive test

\begin{tabular}{|c|c|c|c|c|}
\hline Extract & Animal group & Parasitaemia level & $\%$ suppression & Survival date \\
\hline & CON & $32 \pm 0.97$ & - & $7 \pm 0.36$ \\
\hline & CM200 & $18 \pm 1.73$ & $44^{\mathrm{a} 3, \mathrm{~b} 3, \mathrm{c} 3}$ & $10 \pm 0.33^{a 1, b 3, c 3}$ \\
\hline \multirow[t]{5}{*}{ Crude extract } & CM400 & $7 \pm 0.31$ & $78^{\mathrm{a} 3, \mathrm{~b} 1, \mathrm{c3}}$ & $14 \pm 0.42^{\mathrm{a} 3, \mathrm{~b} 3, \mathrm{c3}}$ \\
\hline & CM600 & $3 \pm 0.40$ & $91^{\mathrm{a} 3}$ & $18 \pm 0.60^{a 3, c 3}$ \\
\hline & CQ25 & $0.0^{\mathrm{a} 3}$ & 100 & $30 \pm 0^{\mathrm{a} 3}$ \\
\hline & CON & $30.43 \pm 0.61$ & - & $7.34 \pm 0.42$ \\
\hline & CF200 & $15.40 \pm 0.43$ & $49.4^{a 3, c 3}$ & $9.00 \pm 0.68^{c 3}$ \\
\hline \multirow[t]{5}{*}{ Chloroform fraction } & CF400 & $10.30 \pm 0.58$ & $66.2^{\mathrm{a} 3, \mathrm{c} 3, \mathrm{e} 3}$ & $13.34 \pm 1.25^{\mathrm{a} 3, \mathrm{c} 3, \mathrm{e} 1}$ \\
\hline & CF600 & $7.34 \pm 0.15$ & $75.9^{\mathrm{a} 3, \mathrm{c} 3, \mathrm{~d} 3, \mathrm{e} 3}$ & $16.50 \pm 1.08^{\mathrm{a} 3, \mathrm{c} 3, \mathrm{e} 3}$ \\
\hline & CQ25 & $0.00 \pm 0.00$ & $100.00^{\mathrm{a} 3}$ & $29.67 \pm 0.34^{\mathrm{a} 3}$ \\
\hline & CON & $34.33 \pm 1.62$ & - & $6.84 \pm 0.17$ \\
\hline & MF200 & $21.61 \pm 0.54$ & $37.1^{\mathrm{a} 3, \mathrm{c} 3}$ & $8.83 \pm 1.14^{c 3}$ \\
\hline \multirow[t]{5}{*}{ Methanol fraction } & MF400 & $16.30 \pm 0.71$ & $52.5^{\mathrm{a} 3, \mathrm{c} 3, \mathrm{e} 2}$ & $8.50 \pm 0.56^{\mathrm{c3}}$ \\
\hline & MF600 & $12.28 \pm 0.52$ & $64.2^{a 3, c 3, d 1, e 3}$ & $10.00 \pm 1.15^{\mathrm{a} 1, c 3}$ \\
\hline & CQ25 & $0.00 \pm 0.00$ & $100.00^{\mathrm{a3}}$ & $30.00 \pm 0.00^{\mathrm{a} 3}$ \\
\hline & CON & $37.47 \pm 0.84$ & - & $7.00 \pm 0.25$ \\
\hline & AF200 & $33.03 \pm 0.94$ & $11.8^{\mathrm{a} 2, \mathrm{c} 3}$ & $7.84 \pm 0.60^{c 3}$ \\
\hline \multirow[t]{3}{*}{ Aqueous fraction } & AF400 & $26.27 \pm 0.69$ & $29.9^{\mathrm{a} 3, \mathrm{c}, \mathrm{e} 3}$ & $8.34 \pm 0.42^{c 3}$ \\
\hline & AF600 & $22.94 \pm 0.79$ & $38.8^{\mathrm{a} 3, \mathrm{c} 3, \mathrm{~d} 3, \mathrm{e} 3}$ & $9.17 \pm 0.31^{a 2, c 3}$ \\
\hline & CQ25 & $0.00 \pm 0.00$ & $100.00^{\mathrm{a} 3}$ & $30.00 \pm 0.00^{\mathrm{a3}}$ \\
\hline
\end{tabular}

Data are expressed as mean $\pm \mathrm{SEM} ; \mathrm{n}=6$; a, compared to control; b, to $600 \mathrm{mg} / \mathrm{kg} ; \mathrm{c}$, to CQ25mg/kg; d, to $400 \mathrm{mg} / \mathrm{kg} ; \mathrm{e}, 200 \mathrm{mg} / \mathrm{kg}:{ }^{1} \mathrm{p}<0.05,{ }^{2} \mathrm{p}<0.01,{ }^{3} \mathrm{p}<0.001$; $\mathrm{CF}=$ Chloroform fraction, $\mathrm{CQ}=$ chloroquine, $\mathrm{MF}$, methanol fraction, $\mathrm{AF}$, aqueous fraction, $\mathrm{CON}=\mathrm{Control}$, CM, crude extract of Croton macrostachys. Numbers refer to dose in $\mathrm{mg} / \mathrm{kg}$.

decrease $(\mathrm{p}<0.001$ in all cases) in level of parasitemia compared to CON mice. CM600 exhibited a significant parasite suppression compared to other doses of the extract and the activity was almost comparable to that of CQ25 (Table 1). The extract was also capable of significantly increasing survival time at all doses compared to controls, but the effect was significantly lower than CQ25.

Analysis of rectal temperature revealed that $80 \%$ methanolic extract of Croton macrostachys caused significant attenuation of reduction in temperature of Plasmodium berghei infected mice in a dose-dependent manner ( $\mathrm{p}<0.01$ for CM200 \& CM400, $\mathrm{p}<0.001$ for CM600). Both CM200 and CM400 had a comparable effect to CQ25, while CM600 appeared to have a better effect, although the result was not statistically significant (Table 2). The extract averted loss of weight associated with infection at all dose levels compared to $\mathrm{CON}$ mice. However, the increase in body weight was not found to be dose-dependent, as maximum effeect was obsreved with CM400 and minimum with CM200. There were no detectable differences in preventing weight reduction associated with parasitemia between the extracts as well as between the extract and CQ25 (Table 2). Neither the extract nor the standard prevented reduction of PCV when compared to $\mathrm{CON}$ animals.

\section{Solvent fractions}

All the fractions dose-dependently reduced parasitemia level compared to CON group, although the extent of reduction was less than that of CQ25, which produced $100 \%$ suppression (Table 1). The rank order of chemosuppression of the solvent fractions was chloroform $(75.9 \%)>$ methanol $(64.2 \%)>$ aqueous (38.8\%). Survival date was significantly prolonged $(\mathrm{p}<0.001)$ by the larger and middle doses of the chloroform fraction but only the larger dose of the methanol $(\mathrm{p}<0.05)$ and aqueous $(\mathrm{p}<0.01)$ fractions was capable of significantly increasing survival date compared to CON mice.

Body weight reduction caused by inoculation of the parasite was not significantly ablated by both chloroform and aqueous fractions. By contrast, all doses of the methanol fraction significantly prevented $(\mathrm{p}<0.001)$ body weight reduction. PCV reduction was dose-dependently attenuated by all doses of the chloroform fraction, but no detectable changes were noted with the other two 
Table 2 Temperature, weight and packed cell volume of infected animals treated with crude extract and solvent fractions of Croton macrostachys in the 4 day suppressive test

\begin{tabular}{|c|c|c|c|c|c|c|c|c|c|c|}
\hline \multirow[t]{2}{*}{ Extract } & \multirow{2}{*}{$\begin{array}{l}\text { Animal } \\
\text { group }\end{array}$} & \multicolumn{3}{|c|}{ Temperature } & \multicolumn{3}{|l|}{ Weight } & \multicolumn{3}{|c|}{ Packed cell volume } \\
\hline & & $\mathrm{DO}$ & D4 & $\%$ change & $\mathrm{DO}$ & D4 & $\%$ change & Do & D4 & $\%$ change \\
\hline \multirow[t]{5}{*}{ Crude extract } & $\mathrm{CON}$ & $37.2 \pm 0.19$ & $37.2 \pm 0.19$ & -2 & $26.0 \pm 0.18$ & $24.0 \pm 0.43$ & -15.5 & $55 \pm 0.33$ & $53 \pm 0.26$ & -3.6 \\
\hline & CM200 & $37.5 \pm 0.08$ & $37.2 \pm 0.07$ & $-0.8^{\mathrm{a} 2}$ & $26.1 \pm 0.12$ & $25.3 \pm 0.34$ & $-5.2^{\mathrm{a} 1}$ & $53 \pm 1.34$ & $53 \pm 1.48$ & 0.0 \\
\hline & CM400 & $37.1 \pm 0.11$ & $37.1 \pm 0.11$ & $0.5^{\mathrm{a} 2}$ & $26.2 \pm 0.11$ & $25.9 \pm 0.15$ & $-0.6^{\mathrm{a} 3}$ & $54 \pm 0.50$ & $55 \pm 0.70$ & 1.8 \\
\hline & CM600 & $37.0 \pm 0.15$ & $37.0 \pm 0.15$ & $1.3^{\mathrm{a} 3}$ & $26.2 \pm 0.17$ & $25.7 \pm 0.22$ & $-2.8^{\mathrm{a} 2}$ & $54 \pm 0.55$ & $56 \pm 0.84$ & 3.5 \\
\hline & CQ25 & $37.2 \pm 0.08$ & $37.2 \pm 0.08$ & $0.2^{\mathrm{a} 2}$ & $26.1 \pm 0.09$ & $25.5 \pm 0.05$ & $-2.4^{\mathrm{a} 2}$ & $53 \pm 0.55$ & $55 \pm 0.42$ & 3.8 \\
\hline \multirow[t]{5}{*}{ Chloroform fraction } & CON & $37.3 \pm 0.42$ & $32.9 \pm 0.21$ & -11.76 & $27.9 \pm 0.82$ & $26.8 \pm 1.15$ & -4.00 & $53.3 \pm 1.46$ & $49.7 \pm 1.61$ & -6.73 \\
\hline & CF200 & $36.9 \pm 0.37$ & $36.3 \pm 0.47$ & $-1.59^{\mathrm{a} 3}$ & $27.17 \pm 0.64$ & $25.15 \pm 1.16$ & $-7.43^{\mathrm{b} 3}$ & $51.7 \pm 1.78$ & $51.1 \pm 1.1$ & $-1.14^{\mathrm{a} 1}$ \\
\hline & CF400 & $37.5 \pm 0.32$ & $37.4 \pm 0.23$ & $-0.48^{\mathrm{a} 3}$ & $27.7 \pm 1.16$ & $26.8 \pm 1.08$ & $-3.82^{\mathrm{b} 2}$ & $52.2 \pm 1.25$ & $52.2 \pm 1.16$ & $0.00^{\mathrm{a} 2}$ \\
\hline & CF600 & $37.7 \pm 0.49$ & $37.4 \pm 0.39$ & $-0.93^{\mathrm{a} 3}$ & $28.1 \pm 1.20$ & $27.9 \pm 1.12$ & $-0.89^{\mathrm{b} 1}$ & $51.7 \pm 1.82$ & $53.3 \pm 1.90$ & $3.23^{\mathrm{a} 3}$ \\
\hline & CQ25 & $37.4 \pm 0.27$ & $37.5 \pm 0.26$ & $0.32^{\mathrm{a} 3}$ & $26.7 \pm 0.51$ & $27.3 \pm 0.83$ & $2.36^{\mathrm{a} 2}$ & $53.2 \pm 0.48$ & $53.9 \pm 0.62$ & $1.35^{\mathrm{a} 2}$ \\
\hline \multirow[t]{5}{*}{ Methanol fraction } & CON & $37.3 \pm 0.21$ & $35.4 \pm 0.17$ & -5.15 & $31.6 \pm 0.47$ & $30.3 \pm 0.89$ & -3.83 & $53.8 \pm 1.61$ & $52.3 \pm 1.05$ & -2.80 \\
\hline & MF200 & $37.7 \pm 0.29$ & $35.2 \pm 0.71$ & $-6.63^{\mathrm{b3}}$ & $26.6 \pm 0.47$ & $27.2 \pm 0.54$ & $2.44^{\mathrm{a} 3}$ & $53.2 \pm 0.98$ & $50.4 \pm 0.70$ & $-5.17^{\mathrm{b} 3}$ \\
\hline & MF400 & $37.9 \pm 0.36$ & $34.4 \pm 0.48$ & $-9.24^{\mathrm{b} 3}$ & $26.8 \pm 0.55$ & $28.1 \pm 0.59$ & $4.43^{\mathrm{a} 3}$ & $52.8 \pm 0.96$ & $51.2 \pm 0.90$ & $-3.00^{\mathrm{b} 2}$ \\
\hline & MF600 & $38.0 \pm 0.15$ & $34.7 \pm 0.23$ & $-8.73^{\mathrm{b3}}$ & $28.1 \pm 0.89$ & $29.4 \pm 0.81$ & $4.52^{\mathrm{a} 3}$ & $50.9 \pm 1.28$ & $51.1 \pm 1.47$ & 0.25 \\
\hline & CQ25 & $36.9 \pm 0.25$ & $37.2 \pm 0.60$ & $0.68^{\mathrm{a} 3}$ & $30.1 \pm 0.93$ & $30.5 \pm 0.83$ & $1.33^{\mathrm{a} 2}$ & $54.8 \pm 1.16$ & $55.7 \pm 0.98$ & $1.68^{\mathrm{a} 1}$ \\
\hline \multirow[t]{5}{*}{ Aqueous fraction } & CON & $37.7 \pm 0.13$ & $34.2 \pm 0.28$ & -9.30 & $31.7 \pm 0.57$ & $30.4 \pm 0.65$ & -3.94 & $55.8 \pm 1.17$ & $53.9 \pm 1.25$ & -3.40 \\
\hline & AF200 & $37.1 \pm 0.46$ & $34.9 \pm 0.32$ & $-5.90^{\mathrm{b} 2}$ & $30.8 \pm 0.79$ & $30.7 \pm 0.54$ & $-0.39^{b 1}$ & $56.8 \pm 0.96$ & $55.3 \pm 0.54$ & $-2.64^{\mathrm{b} 1}$ \\
\hline & AF400 & $36.7 \pm 0.25$ & $34.9 \pm 0.27$ & $-5.20^{\mathrm{b} 2}$ & $29.2 \pm 0.86$ & $28.9 \pm 0.75$ & $-1.04^{\mathrm{b} 1}$ & $54.4 \pm 1.85$ & $54.2 \pm 0.21$ & -0.46 \\
\hline & AF600 & $36.6 \pm 0.35$ & $34.9 \pm 0.56$ & $-4.97^{\mathrm{b} 2}$ & $30.0 \pm 1.04$ & $29.0 \pm 0.90$ & $-3.26^{\mathrm{b} 2}$ & $56.4 \pm 1.14$ & $55.8 \pm 0.77$ & $-1.19^{\mathrm{b} 1}$ \\
\hline & CQ25 & $36.9 \pm 0.35$ & $36.6 \pm 0.26$ & $-1.00^{\mathrm{a} 3}$ & $28.1 \pm 1.08$ & $28.8 \pm 1.18$ & $2.56^{\mathrm{a} 2}$ & $55.5 \pm 0.79$ & $56.1 \pm 0.55$ & $1.04^{\mathrm{a} 1}$ \\
\hline
\end{tabular}

Data are expressed as mean $\pm \mathrm{SEM} ; \mathrm{n}=6$; $\mathrm{a}=$ compared to control, $\mathrm{b}=$ to chloroquine $25 \mathrm{mg} / \mathrm{kg} ;{ }^{1} \mathrm{p}<0.05 ;{ }^{2} \mathrm{p}<0.01,{ }^{3} \mathrm{p}<0.001 ; \mathrm{D} 0=\mathrm{pre}$-treatment value on day 0 , D4 = post-treatment value on day four, $\mathrm{CF}=$ Chloroform fraction, $\mathrm{CQ}=$ chloroquine, $\mathrm{MF}$, methanol fraction, $\mathrm{AF}$, aqueous fraction, $\mathrm{CON}=\mathrm{Control}, \mathrm{CM}$, crude extract of Croton macrostachys. Numbers refer to dose in $\mathrm{mg} / \mathrm{kg}$.

fractions. Moreover, all doses of the chloroform fraction significantly $(\mathrm{p}<0.001)$ prevented the reduction in rectal temperature caused by escalating parasitemia and the effect was comparable to that observed with CQ25 mice (Table 2).

\section{Effect on curative test Crude extract}

The crude extract dose-dependently reduced $(\mathrm{p}<0.001$ in all cases) parasitemia by 39, 69 and $83 \%$ for CM200, CM400 and CM600, respectively, compared to CON mice (Table 3). The inhibition obtained by CQ25 was significantly higher than CM200 $(\mathrm{p}<0.001)$ and CM400 $(\mathrm{p}<0.05)$ but, no apparent difference was observed with CM600. Survival time was not altered by CM200 but significantly increased by CM400 ( $<<0.001)$ and CM600 $(\mathrm{p}<0.001)$, however, the increase achieved with the extract was no match to that of CQ25 (Table 3). Rectal temperature analysis indicated that the extract had a significant preventive effect on the reduction in temperature at all doses compared to CON animals. Comparison of the doses amongst themselves as well as with CQ25, however, did not reveal any apparent changes (Table 4). Similar to the 4 day suppressive test, all doses of the extract failed to show any protective activity against the reduction in PCV (Table 4). The extract exhibited a preventive effect in weight reduction in infected mice at all dose levels compared to CON mice. However, the increase in body weight was not dose-dependent. No significant difference was noted in prevention of parasiteinduced weight reduction when comparison was performed amongst the extract doses as well as with CQ25 (Table 4).

\section{Solvent fractions}

The fraction with the highest antimalarial activity (chloroform fraction) in the four day suppressive test was further evaluated for its effect on established parasite infection. Chloroform fraction exhibited a dosedependent reduction $(\mathrm{p}<0.001)$ of parasitemia compared to CON animals in the Rane's test (Table 3). Maximum inhibition $(82.3 \%)$ was attained with $600 \mathrm{mg} / \mathrm{kg}$ dose of the fraction. On the other hand, CQ25 cleared the parasite to undetectable level on day 7 and the reduction in 
Table 3 Parasitaemia and survival of infected animals treated with crude extract and chloroform fraction of Croton macrostachys in the Rane's test

\begin{tabular}{|c|c|c|c|c|c|c|c|c|}
\hline Extract & Group & Day 3 & Day 4 & Day 5 & Day 6 & Day 7 & $\%$ inhibition & Survival date \\
\hline \multirow[t]{5}{*}{ Crude extract } & $\mathrm{CON}$ & $9 \pm 0.15$ & $16 \pm 0.13$ & $14 \pm 0.23$ & $31 \pm 0.61$ & $36 \pm 1.1$ & - & $6 \pm 0.31$ \\
\hline & CM200 & $12 \pm 0.36$ & $28 \pm 1.20$ & $26 \pm 0.32$ & $25 \pm 0.16$ & $22 \pm 0.19$ & $39^{\mathrm{a} 3, \mathrm{~b} 3, \mathrm{c3}}$ & $7 \pm 0.31^{b 3, c 3}$ \\
\hline & CM400 & $11 \pm 0.43$ & $19 \pm 0.95$ & $16 \pm 0.85$ & $14 \pm 0.54$ & $11 \pm 0.95$ & $69^{\mathrm{a} 3, \mathrm{c} 1}$ & $12 \pm 0.47^{\mathrm{a}, \mathrm{b} \mathrm{b}, \mathrm{c3}}$ \\
\hline & CM600 & $10 \pm 0.32$ & $14 \pm 0.56$ & $11 \pm 0.47$ & $8 \pm 0.41$ & $7 \pm 0.78$ & $83^{\mathrm{a} 3}$ & $16 \pm 0.42^{\mathrm{a}, \mathrm{c} 3}$ \\
\hline & CQ25 & $11 \pm 0.22$ & $5 \pm 0.09$ & $2 \pm 0.56$ & 0 & $0.00 \pm 0.00$ & $100^{\mathrm{a3}}$ & $30 \pm 0^{\mathrm{a} 3}$ \\
\hline \multirow[t]{5}{*}{ Chloroform fraction } & CON & $21.8 \pm 0.58$ & $26.6 \pm 0.90$ & $33.1 \pm 0.81$ & $40.7 \pm 0.67$ & $54.6 \pm 1.34$ & - & $7.2 \pm 0.31$ \\
\hline & CF200 & $20.8 \pm 0.83$ & $20.8 \pm 0.66$ & $20.2 \pm 0.92$ & $19.8 \pm 0.50$ & $18.5 \pm 0.63$ & $66.2^{\mathrm{a} 3, \mathrm{c} 3}$ & $7.5 \pm 0.34^{c 3}$ \\
\hline & CF400 & $22.7 \pm 0.63$ & $21.2 \pm 0.51$ & $17.4 \pm 0.45$ & $15.4 \pm 0.49$ & $13.5 \pm 0.80$ & $75.3^{\mathrm{a} 3, \mathrm{c} 3, \mathrm{e} 2}$ & $10.3 \pm 0.76^{\mathrm{a} 2, \mathrm{~d} 3}$ \\
\hline & CF600 & $21.8 \pm 0.79$ & $20.9 \pm 0.62$ & $15.4 \pm 1.02$ & $11.5 \pm 0.45$ & $9.7 \pm 0.65$ & $82.3^{\mathrm{a} 3, \mathrm{c}, \mathrm{d} 1 \mathrm{~d}, \mathrm{e3}}$ & $12.3 \pm 0.72^{\mathrm{a} 3, \mathrm{c} 3, \mathrm{e} 3}$ \\
\hline & CQ25 & $20.8 \pm 0.85$ & $15.6 \pm 1.02$ & $5.5 \pm 0.28$ & $1.5 \pm 0.29$ & $0.00 \pm 0.0$ & $100^{\mathrm{a} 3}$ & $30.0 \pm 0.0^{\mathrm{a} 3}$ \\
\hline
\end{tabular}

Data are expressed as mean $\pm \mathrm{SEM} ; \mathrm{n}=6$ : a, compared to control; $\mathrm{b}$, to $600 \mathrm{mg} / \mathrm{kg} ; \mathrm{c}$, to CQ $25 ; \mathrm{d}$, to $400 \mathrm{mg} / \mathrm{kg} ; \mathrm{e}$, to $200 \mathrm{mg} / \mathrm{kg}:{ }^{1} \mathrm{p}<0.05,{ }^{2} \mathrm{p}<0.01,{ }^{3} \mathrm{p}<0.001$; $\mathrm{CF}=$ Chloroform fraction, $\mathrm{CQ}=$ chloroquine, MF, methanol fraction, $\mathrm{AF}$, aqueous fraction, $\mathrm{CON}=\mathrm{Control}, \mathrm{CM}$, crude extract of Croton macrostachys. Numbers refer to dose in $\mathrm{mg} / \mathrm{kg}$.

parasitaemia was significantly higher $(\mathrm{p}<0.001)$ compared to CON as well as all doses of the fraction.

As shown in Table 3, lower dose of chloroform fraction was not associated with significant prolongation of survival time. Although the middle $(\mathrm{p}<0.01)$ and larger $(\mathrm{p}<0.001)$ doses of the fraction did significantly prolong survival time compared to $\mathrm{CON}$ mice, the effect was still much lower $(\mathrm{p}<0.001)$ than attained by CQ25. All doses of the fraction as well as CQ25 were shown to significantly $(\mathrm{p}<0.001)$ prevent the reduction in temperature compared to CON group. CQ25 halted temperature dropping significantly compared to CF200 (p<0.05). However, there was no significant difference compared to the middle and larger doses of the fraction (Table 5).

\section{Phytochemical screening}

Phytochemical screening of the hydroalcoholic crude extract of the leaves of Croton macrostachyus revealed the presence of alkaloids, saponins, phenolic compounds, cardiac glycosides, tannins, terpenoids and flavonoids. Anthraquinones and phlabotannins were, however, absent from the crude extract. Phytochemical composition of the different fractions is depicted in Table 6. The methanol fraction appeared to be rich in secondary metabolites compared to the other two fractions.

\section{Discussion}

The in vivo model was employed for this study because it takes into account the possible prodrug effect and possible involvement of the immune system in eradication of infection [24]. Plasmodium berghei ANKA was used in the prediction of treatment outcomes [33] and hence it was an appropriate parasite for the study. Moreover, several conventional antimalarial agents such as chloroquine, halofantrine, mefloquine and more recently artemisinin derivatives have been identified using rodent model of malaria [34].

The 4 day suppressive test, which mainly evaluates the antimalarial activity of candidates on early infections, and Rane's test, which evaluates the curative capability of candidate extracts on established infections, are commonly used for antimalarial drug screening. In both methods, determination of percent inhibition of parasitemia is the most reliable parameter. A mean parasitemia level $\leq 90 \%$ to that of mock-treated control animals usually indicates that the test compound is active in standard screening studies [35].

Table 4 Rectal temperature, weight and packed cell volume of infected animals treated with crude extract of Croton macrostachys in the Rane's test

\begin{tabular}{llllllllll}
\hline Animal group & T0 & T4 & \% change & W0 & W4 & \% change & PCV0 & PCV4 & \% change \\
\hline CON & $37.4 \pm 0.14$ & $36.6 \pm 0.05$ & -2.2 & $26.2 \pm 0.21$ & $22.1 \pm 0.43$ & -7.7 & $54 \pm 0.31$ & $53 \pm 0.21$ & -4.9 \\
CM200 & $37.3 \pm 0.08$ & $37.2 \pm 0.08$ & $-0.2^{\mathbf{a} 2}$ & $26.3 \pm 0.11$ & $25 \pm 0.16$ & $-3.1^{\mathbf{a} 1}$ & $53 \pm 0.31$ & $52 \pm 0.40$ & -1.9 \\
CM400 & $37.4 \pm 0.09$ & $37.4 \pm 0.04$ & $0.0^{\mathbf{a} 3}$ & $26.4 \pm 0.11$ & $26.3 \pm 0.05$ & $-1.1^{\mathbf{a} 3}$ & $52.5 \pm 0.43$ & $53 \pm 0.22$ & 0.9 \\
CM600 & $37.3 \pm 0.09$ & $37.4 \pm 0.03$ & $0.2^{\mathbf{a} 3}$ & $26.6 \pm 0.06$ & $25.9 \pm 0.05$ & $-1.8^{\mathbf{a} 2}$ & $52 \pm 0.31$ & $53 \pm 0.44$ & 1.9 \\
CQ25 & $37.4 \pm 0.18$ & $37.3 \pm 0.13$ & $-0.2^{\mathbf{a} 2}$ & $26.5 \pm 0.04$ & $25.9 \pm 0.04$ & $-2.3^{\mathbf{a} 2}$ & $52.5 \pm 0.42$ & $53 \pm 0.21$ & 2.4 \\
\hline
\end{tabular}

Data are expressed as mean $\pm \mathrm{SEM} ; \mathrm{n}=6$; a,compared to controls, ${ }^{1} \mathrm{p}<0.05,{ }^{2} \mathrm{p}<0.01,{ }^{3} \mathrm{p}<0.001 ; \mathrm{CM}$, crude extract of Croton macrostachys; $\mathrm{W}$, weight; $\mathrm{T}$, temperature; PCV, packed cell volume; 0 refers at day 0 and 4 to day 4 . Numbers refer to dose in $\mathrm{mg} / \mathrm{kg}$. 
Table 5 Effect of the chloroform fraction of Croton macrostachyson on rectal temperature of Plasmodium berghei infected mice in the Rane's test

\begin{tabular}{lllllll}
\hline Group & Day 0 & Day 3 & Day 4 & Day 5 & Day 6 & Day 7 \\
\hline Control & $37.25 \pm 0.21$ & $34.05 \pm 0.15$ & $34.08 \pm 0.19$ & $33.48 \pm 0.26$ & $33.53 \pm 0.21$ & $32.75 \pm 0.16$ \\
CM200 & $37.48 \pm 0.3$ & $33.38 \pm 0.21$ & $34.48 \pm 0.33$ & $34.76 \pm 0.27$ & $35.62 \pm 0.26$ & $36.43 \pm 0.24^{\mathrm{a} 3, \mathrm{~b} 1}$ \\
CM400 & $37.48 \pm 0.22$ & $33.38 \pm 0.38$ & $34.53 \pm 0.37$ & $34.15 \pm 0.23$ & $36.05 \pm 0.25$ & $36.62 \pm 0.21^{\mathrm{a} 3}$ \\
CM600 & $37.50 \pm 0.21$ & $33.64 \pm 0.32$ & $33.91 \pm 0.26$ & $35.74 \pm 0.14$ & $36.50 \pm 0.28$ & $36.91 \pm 0.13 \mathrm{a} 3$ \\
CQ25 & $37.32 \pm 0.23$ & $33.92 \pm 0.32$ & $34.67 \pm 0.24$ & $35.65 \pm 0.29$ & $37.13 \pm 0.19$ & $37.40 \pm 0.19^{\mathrm{a} 3}$ \\
\hline
\end{tabular}

Data are expressed as mean \pm SEM for six mice per group; $a=$ compared to controls, $b=$ to chloroquine $25 \mathrm{mg} / \mathrm{kg} ; 1=\mathrm{p}<0.05 ; 3=\mathrm{p}<0.001, \mathrm{CQ}=\mathrm{chloroquine}$.

It can be clearly seen from the results that percentage parasitemia measured in the 4 day test was reduced by the crude extract in Plasmodium berghei infected mice, pointing to the fact that the plant is endowed with antimalarial activity. Evidence comes for this assertion from studies that reported antimalarial activity of other species of the same genus such as Croton zambesicus [36]. Among the fractions, the chloroform and methanol fractions were found to possess higher blood schizontocidal activity than the aqueous fraction. This was evident from the chemosuppression obtained during the four day suppressive test, suggesting the possible localization of the active ingredients in these two fractions. Alkaloids, phenolic compounds and terpenoids present in these fractions could be responsible for their antimalarial activity. The alkaloids are known to possess antiplasmodial properties, the most famous being quinine. The highest antimalarial activity of the chloroform fraction was found to be similar with other reports that came out from in vitro [37] and in vivo [38] studies. The phytochemical constituents of chloroform and methanol fractions may have an individual or synergistic effect to exert their antimalarial activity. But traces may be found in the aqueous fraction, which could explain its lower antimalarial activity. Crude extract of Croton macrostachys is reported to possess in vitro antiplasmodial activity [17] as well as larvicidal property [18]. Moreover,

Table 6 Phytochemical constituents of crude extract and solvent fractions of Croton macrostachys

\begin{tabular}{lllll}
\hline $\begin{array}{l}\text { Secondary } \\
\text { metabolites }\end{array}$ & $\begin{array}{l}\text { Crude } \\
\text { extract }\end{array}$ & $\begin{array}{l}\text { Chloroform } \\
\text { extract }\end{array}$ & $\begin{array}{l}\text { Methanol } \\
\text { extract }\end{array}$ & $\begin{array}{l}\text { Aqueous } \\
\text { extract }\end{array}$ \\
\hline Alkaloids & + & + & + & + \\
Saponins & + & - & + & + \\
Phenolic compounds & + & + & + & - \\
Cardiac glycosides & + & - & + & - \\
Tannins & + & - & + & + \\
Flavonoids & + & - & + & - \\
Terpenoids & + & + & - & - \\
Anthraquinones & - & - & - & - \\
Phlobatannins & - & - & - & - \\
\hline
\end{tabular}

- , absent; +, present. antimicrobial activity has been attributed to the crude extract $[15,16,39]$, where the chloroform and butanol fractions showing greater growth inhibitory, while the aqueous fraction lacking any growth inhibition effect [40]. Drugs with antibacterial activity such as tetracycline and its derivatives are employed in the treatment of malaria. These observations further reinforce the notion that compounds responsible for antimalarial activity of the plant might be concentrated in non-polar and semipolar fractions.

Anemia, body weight loss and body temperature reduction are the general features of malaria-infected mice [41]. So, an ideal antimalarial agents obtained from plants are expected to prevent body weight loss in infected mice due to the rise in parasitemia. Despite the fact that the increase in weight was not consistent with increase in dose, the crude extract of Croton macrostachys significantly prevented weight loss associated with increase in parasitemia level. The preventive effect declined at the highest dose (CM600) which is consistent with the results of the parallel sub-acute toxicity study carried out to rule out the effect of the extract on the measured parameters. The fact that the preventive effect decreased with increasing dose might indicate that the plant could have appetite suppressive effect at higher doses. This appetite suppressive activity might be ascribed to saponins, flavonoids, glycosides and phenolic compounds found in the crude extract [42]. Unlike the crude extract, the chloroform and aqueous fractions did not protect animals from body weight loss but the methanol fraction did. This suggests the possibility of the localization of appetite suppressing components in these fractions [43] and nutrients and other immunomodulatory substances in the methanol fraction [33].

A decrease in the metabolic rate of infected mice occurs before death and is accompanied by a corresponding decrease in internal body temperature [44]. Ideally, the rectal temperature decreases as parasite level escalates. Active compounds should prevent the rapid dropping of rectal temperature. The crude extract and the chloroform fraction did have protective effects against temperature reduction, which reflects constituents responsible for this effect were likely found in this fraction. 
PCV was measured to evaluate the effectiveness of the crude extract and fractions in preventing hemolysis due to escalating parasitaemia level. The underlying cause of anemia includes the following mechanisms; the clearance and/or destruction of infected RBCs, the clearance of uninfected RBCs, and erythropoietic suppression and dyserythropoiesis. Each of these mechanisms has been implicated in both human and mouse malarial anemia [45]. One could note that the chloroform fraction was the only one that ablated PCV reduction. This observation is consistent with studies conducted on chloroform fraction of other plants, including Dodonea Angustifolia [46]. Failure of the crude extract and the two fractions to reverse PCV reduction could probably be related to the presence of saponins in the extract, which are known to have strong hemolytic effects [46].

In the curative test, blood samples were taken and smears prepared daily to evaluate the curative ability of the extract. As indicated in the results section, all doses of the crude extract and fractions brought about reduction of parasitemia after second dose, however, the standard drug chloroquine started its activity right after the first dose. This delay of activity may be indicative of the need for a loading dose or the extract might have a delayed onset of action. The curative effect of chloroform fraction occurred in a dose-dependent manner, with the highest suppression observed with its higher dose, and this is in line with previous reports $[38,47]$. Furthermore, the chloroform fraction prolonged the mean survival time in established parasite infection, which is also concordant with the study conducted on Melanthra scandens [38]. Taken together, the results obtained from the Rane's test suggest that the chloroform fraction has therapeutic efficacy against established malaria parasite. This property is additive to the suppressive activity and it may be possible to consider the plant as a potential source of antimalrial agents, as it is desirable to have both activities in a potential phytodrug [48].

Although the active compound is yet to be identified, the antimalarial activity of Croton macrostachyus could be attributed to a single or a combination of its secondary metabolites such as alkaloids, flavonoids, terpenoids and phenolic compounds. These metabolites have been reported to have different extent of antimalarial activity in the literature [49-51]. Many species of the genus Croton were also reported to have promising antimalarial activity in different in vitro and in vivo studies [52,53].

In vivo antiplasmodial activity can be classified as moderate, good, and very good if an extract displayed percentage parasitemia suppression equal to or greater than $50 \%$ at a dose of 500, 250 and $100 \mathrm{mg} / \mathrm{kg}$ body weight per day, respectively $[54,55]$. Based on this classification, the crude extract as well as the chloroform and methanol fractions of the studied plant showed good antiplasmodial activity.

\section{Conclusions}

The present study indicates that $80 \%$ methanolic extract and solvent fractions of Croton macrostachys have good antiplasmodial activity, with varying degree and/or differential effect on the measured parameters. The crude extract appeared to be superior in supressing parsitemia but was devoid of effect in protecting infected animals from parasite-induced $\mathrm{PCV}$ reduction. Although the chloroform fraction protected PCV reduction and displayed greater parasite suppression among the fractions, it failed to have a benefcial effect on body weight reduction. The findings suggest that the phytochemicals responsible for antimalarial activity of the plant are nonpolar to semi-polar in nature and future studies on the plant regrading antimalarial activity should be conducted using the crude extract. In addition, the data would provide evidence to uphold the earlier in vitro findings as well as the claims made by the Ethiopian traditional medicine practioners.

\section{Competing interests}

We declare that there are no conflicts of interest to disclose.

\section{Authors' contributions}

LB and SA conducted the actual study and the statistical analysis. TT and EE were involved in developing the idea and desgining of the study. LB and EE were also involved in the write up of the manuscript. All authors approved the submitted version of the manuscript.

\section{Acknowledgment}

The financial support of Addis Ababa University is gratefully acknowledged.

\section{Author details}

'Department of Pharmacology and Clinical Pharmacy, School of Pharmacy, Addis Ababa University, P.O, Box 1176, Addis Ababa, Ethiopia. ${ }^{2}$ Aklilu Lemma Institute of Pathobiology, Addis Ababa University, Addis Ababa, Ethiopia.

Received: 21 November 2013 Accepted: 26 February 2014 Published: 1 March 2014

\section{References}

1. World Economic Forum: Business and Malaria: A neglected threat? Geneva, Switzerland: Global Health Initiative in cooperation with School of Public health, Harvard University; 2006

2. World Health Organization: World malaria report. Geneva, Switzerland; 2008. 3. World Health Organization: World malaria report. Geneva, Switzerland; 2010.

4. Irungu BN, Mbabu MJ, Kiboi DM, Moindi E, Kinyua J, Romano M: In vivo antimalarial and acute toxicity properties of hexane and chloroform extracts from Clausena anisata (Willd.). Benth AJPT 2012, $1: 24-29$.

5. Rosenthal JP: Antimalarial drug discovery, old and new approaches. J Exp Biol 2003, 206:3735-3744.

6. Wright WC: Plant derived antimalarial agents, new leads and challenges Phytochem Rev 2005, 4:55-61.

7. Batista R, Júnior SJA, Oliveira BA: Plant-Derived Antimalarial Agents, new Leads and Efficient Phytomedicines, part II, Non-Alkaloidal Natural Products. Molecules 2009, 14:3037-3072

8. Kapingu CM, Guillaume D, Mbwambo HZ, Moshi JM, Uliso CF, Mahunnah ALR: Diterpenoids from the roots of Croton macrostachys. Phytochem 2000, 54:767-770. 
9. Orwa C, Mutua A, Kindt R, Jamnadass R, Simons A: Agroforestry Database: a tree reference and selection guide version4. 2009. http://www.worldagroforestry. org/treedb2/AFTPDFS/Croton_macrostachyus.pdf accessed on 2 April 2012.

10. Gidey M, Tekilehaimanot T, Animut A, Mekonen Y: Medicinal plants of Shinasha, Agew-awi and Amhara peoples in North West Ethiopia. J Ethnopharmacol 2007, 110:516-525.

11. Tala MF, Tan N-H, Ndonsta BL, Tane P: Triterpinoids and phenolic commpounds from Croton macrostchyus. Biochem Syst Ecolo 2013, 51:138-141.

12. Kalayou S, Haileselassie M, Gebre-Egziabher G, Tikue T, Sahle S, Taddele H, Ghezu M: In vivo antimicrobial activity screening of some ethnoveterinary medicinal plants traditionally used against mastitis, wound and gastrointestinal tract complications in Tigray Region, Ethiopia. Asian Pac J Trop Biomed 2012, 2:516-522.

13. Mazzanti G, Bolle P, Martinoli L, Piccinelli D, Grqurina I, Animati F, Mugne Y: Croton macrostachys, a plant used in traditional medicine: purgative and inflammatory activity. J Ethnopharmacol 1987, 19:213-219.

14. Mathieu T, Blanche LD, Pierre T, Jean DT, Jules RK: Diterpinoids \& triterpinoids from stem bark of Croton macrostachys. Int J Biol Chem Sci 2009, 3:538-544

15. Desta B: Ethiopian traditional herbal drugs. Part II: Antimicrobial activity of 63 medicinal plants. J Ethnopharmacol 1993, 39:129-139.

16. Taniguchi M, Kubo I: Ethnobotanical drug discovery based on medicine men's trials in the African savanna: Screening of East African Plants for antimicrobial activity II. J Nat Prod 1993, 56:1539-1546.

17. Sorsa S: In vitro evaluation of the activity of some Ethiopian traditional medicinal plants against Plasmodium falciparum. [MSc Thesis]. Addis Ababa University: Department of Biology; 1992.

18. Karunamoorthi K, llango K: Larvicidal activity of Cymbopogon citratus (DC) Stapf. and Croton macrostachyus against Anopheles arabiensis Patton, a potent malaria vector. Eur Rev Med Pharmacol Sci 2010, 14:57-62.

19. Kassaye KD, Amberbir A, Getachew B, Mussema Y: A historical overview of traditional medicine practices and policy in Ethiopia. Ethiop J Health Dev 2006, 20:127-134.

20. Tekalign $\mathrm{D}$, Yalemtsehay $\mathrm{M}$, Abebe $\mathrm{A}$ : In vivo antimalarial activitiy of Clerodendrum myricoids, Dodonea augustifolia and Aloe debrana against Plasmodium berghei. Ethiop J Health Dev 2010, 24:25-29.

21. The Organization of Economic Co-operation and Development (OECD): The OECD guidelines for testing of chemicals 420, acute oral toxicity. France; 2001

22. Seidel V: Initial and bulk extraction. In Methods in Biotechnology Natural Products Isolation. 2nd edition. Edited by Sarker SA, Latif Z, Gray Al. New Jersey: Humana press; 2006:27-46

23. Center for Drug Evaluation and Research: Guidance for industry single dose acute toxicity testing for chemicals; 1996.

24. Waako PJ, Gumede B, Smith P, Folb PI: The in vitro and in vivo antimalarial activity of Cardiospermum halicacabum and Momordica foetida. J Ethnopharmacol 2005, 99:137-143.

25. Peter $W$, Portus $H$, Robinson $L$ : The four-day suppressive in vivo antimalarial test. Ann Trop Med Parasitol 1995, 69:155-171.

26. Ryley JF, Peters W: The antimalarial activity of some quinoline esters. Ann Trop Med Parasitol 1995, 84:209-222.

27. Hilou A, Nacoulma G, Guiguemde TR: In vivo antimalarial activities of extracts from Amaranthus spinosus and Boerhaavia erecta in mice. J Ethnopharmacol 2006, 103:236-240.

28. Kalra BS, Chawla S, Gupta P, Valecha N: Screening of antimalarial drugs. Ind J Pharmacol 2006, 38:5-12.

29. Evans WC: Trease and Evans Pharmacognosy. 13th edition. Philadelphia: W.B. Saunders company; 1989.

30. Jones P, Kinghorn D: Extraction of Plant Secondary Metabolites. In Methods in Biotechnology Natural Products Isolation. 2nd edition. Edited by Sarker D, Latif Z, Gray A. Nerw Jersey: Human Press; 2006:323-351.

31. Sofowara A: Medicinal plants and traditional medicines in Africa. 2nd edition Ibadan: Spectrum books; 1993.

32. World Health Organization: The promotion and development of traditional medicine, Technical report series, 622. Geneva; 1987.

33. Dikasso D, Mekonnen E, Debella A, Abebe D, Urga K, Menonnen W, Melaku D, Assefa A, Meknonnen Y: In vivo antimalarial activity of hydroalcoholic extracts from Asparagus africanus Lam. in mice infected with Plasmodium berghei. Ethiop J Health Dev 2006, 20:112-118.

34. Madara A, Ajayi JA, Salawu OA, Tijani AY: Anti-malarial activity of ethanolic leaf extract of Piliostigma thonningii Schum. (Caesalpiniacea) in mice infected with Plasmodium berghei berghei. Afr J Biotechnol 2010, 9:3475-3480.
35. Peter IT, Anatoli VK: The current global malaria situation. Malaria parasite biology, pathogenesis, and protection. W.D.C: ASM press; 1998:11-22.

36. Okokon JE, Ofodum KC, Ajibesin KK, Danladi B, Gamanil KS: Pharmacological screeining and evaluation of antiplasmodial activity of Croton Zambesicus against plasmodium berghei in mice. Ind J Pharmacol 2005, 379:243-246.

37. Bero J, Ganfon H, Jonville M, Frederich M, Gbaguidi F, DeMol P, Moudachirou M: In vitro antiplasmodial activity of plants used in Benin in traditional medicine to treat malaria. J Ethnopharmacol 2009, 122:439-444.

38. Okokon JE, Etebong EO, Udobang JA, Obot J: Antiplasmodial and antiulcer activities of Melanthera scadens. Asian Pacific J Trop Biomed 2012, 2:16-20.

39. Geyid A, Abebe D, Debella A, Mekonnen Z, Aberra F, Teka F, Kebede T, Urga K, Yersaw K, Biza T, H/Mariam B, Guta M: Screening of some medicinal plants of Ethiopia for their anti-microbial properties and chemical profiles. J Ethnopharmacol 2005, 97:421-427.

40. Tefera M: In vitro evaluation of antimicrobial activities of Albizia gummifera and croton macrostachyus against clinical isolates of Neisseria gonorrhoeae. MSc thesis: Department of Biology, Addis Ababa University; 2006.

41. Langhorne J, Quin SJ, Sanni LA: Mouse Models of Blood-Stage Malaria Infections: Immune Responses and Cytokines Involved in Protection and Pathology. In Malaria Immunology. 2nd edition. Edited by Perlmann P, Troye-Blomberg M. Stockholm: Karger publisher; 2002:204-228.

42. Yen WJ: Possible anti-obesity therapeutics from nature- $\mathrm{A}$ review. Phytochem 2010, 71:1625-1641.

43. Chinchilla M, Guerrero OM, Abarca G, Barrios M, Castro O: An in vivo model to study the anti-malaria capacity of plant extracts. Rev Biol Trop 1998, 46:1-7.

44. Mengiste B, Mekonnen E, Urga K: In vivo animalarial activity of Dodonaea angustifolia seed extracts against Plasmodium berghei in mice model. MEJS 2012, 4:147-163.

45. Lamikanra AA, Brown D, Potocnik A, Casals-Pascual C, Langhorne J, Roberts DJ: Malarial anemia of mice and men. J Blood 2007, 110:18-28.

46. Yang ZG, Sun HX, Fang WH: Hemolytic activities and adjuvant effect of Astragalus membranaceus saponins on the immune responses to ovalbumin in mice. Vaccine 2005, 23:5196-5203.

47. Okokon JE, Effiong I, Ettebong E: In vivo antimalarial activities of ethanolic crude extracts and fractions of leaf and root of Carpolobia lutea. Pak J Pharm Sci 2011, 24:57-61.

48. Akuodor GC, Usman IM, Anyalewechi NA, Eucheria O, Ugwu TC, Theresa C, Akpan JL, Gwotmut MD, Osunkwo UA: In vivo antimalarial activity of ethanolic leaf extract of Verbena hastata against Plasmodium berghei berghei in mice. J Her Med Toxico 2010, 4:17-23.

49. Oliveira AB, Dolabela MF, Braga FC, Jácome RLRP, Varotti FP, Póvoa MM: Plant derived antimalarial agents: new leads and efficient phytomedicines. Part I. Alkaloids. Ann Braz Acad Sci 2009, 81:715-740

50. Kaur K, Jain M, Kaur T, Jain R: Antimalarials from nature. Bioorg \& Med Chem 2009, 17:3229-3256.

51. Ferreira A, Balla J, Jeney V, Balla G, Soares MP: A central role for free heme in the pathogenesis of severe malaria: the missing link. J Mol Med 2008, 86:1097-1111.

52. Okokon JE, lyadi K, Effiong C: Effect of sub chronic administration of ethanolic leaf extract of Croton zambesicus on haematological parameters of rats. Nig J Physiol Sci 2004, 19:10-13.

53. Boyom FF, Kemgne EM, Tepongning R, Mbacham WF, Tsamo E, Zollo PHA Antiplasmodial activity of extracts from seven medicinal plants used in malaria treatment in Cameroon. J Ethnopharmacol 2009, 123:483-488.

54. Deharo E, Bourdy G, Quenevo C, Munoz V, Ruiz G, Sauvain M: A search for national bioactive compounds in Bolivia through a multidisciplinary approach. Part V. Evaluation of the antimalarial activity of plants used by the Tecana Indians. J Ethnopharmacol 2001, 77:91-98.

55. Munoz V, Sauvain M, Bourdy G, Callapa J, Bergeron S, Rojas I, Bravo JA, Balderrama L, Ortiz B, Gimenez A, Deharo E: A search for natural bioactive compounds in Bolivia through a multidisciplinary approach. Part I. Evaluation of the antimalarial activity of plants used by the Chacobo Indians. J Ethnopharmacol 2000, 69:127-137.

doi:10.1186/1472-6882-14-79

Cite this article as: Bantie et al:: In vivo antimalarial activity of the crude leaf extract and solvent fractions of Croton macrostachyus Hocsht. (Euphorbiaceae) against Plasmodium berghei in mice. BMC

Complementary and Alternative Medicine 2014 14:79. 